\title{
Seneca's Medea and De ira: Justice and Revenge
}

\author{
Rodrigo Sebastián Braicovich
}

I try to show that Seneca's Medea provides us with two elements - which, as far as I am aware, have not received proper attention - that complement his approach to the phenomenon of anger, and which can improve our understanding of the Stoic psychology of action defended in De ira. The first element is linked to the question of whether the angry person is responsive to reasons or not; the second one concerns the question of indifference, tolerance and forgiveness, and addresses the issue of Medea's inability to conceive of a more appropriate or desirable reaction to Jason's offense than anger.

\section{Introduction}

Among other things, Medea can certainly be seen as the fulfillment of a promise made (and only partially fulfilled) by De ira:

Necessarium est itaque foeditatem eius ac feritatem coarguere et ante oculis ponere quantum monstri sit homo in hominem furens quantoque impetu ruat non sine pernicie sua perniciosus et ea deprimens quae mergi nisi cum mergente non possunt. Quid ergo? sanum hunc aliquis uocat qui uelut tempestate correptus non it sed agitur et furenti malo seruit, nec mandat ultionem suam sed ipse eius exactor animo simul ac manu saeuit, carissimorum eorumque quae mox amissa fleturus est carnifex? [...] Caducae sinistraeque sunt uires et in malum suum ualidae in quas aegrum morbus et accessio erexit. (De ira 3.3.2-3)

Ne irascamur praestabimus, si omnia uitia irae nobis subinde proposuerimus et illam bene aestimauerimus. Accusanda est apud nos, damnanda; perscrutanda eius mala et in medium protrahenda sunt; ut qualis sit appareat, comparanda cum pessimis est. (De ira 3.5.3) ${ }^{2}$

1 "It's necessary to prove its disgusting and bestial character and to make you see how monstrous it is for one human being to rage against another, and how violently anger attacks, dealing destruction at the cost of its own destruction and seeking to sink those whom it can drown only if it drowns with them. Does anyone really call sane a man who doesn't move on his own but is made to move as though in a hurricane's grip, who is a slave to a frenzied evil, who doesn't delegate the job of taking vengeance but acts as his own avenger, savage in thought and deed at once, butchering those dearest to him and those he'll mourn as soon as they're lost? [...] Its strength is fleeting and sinister, capable only of harming itself, the sort of strength that the onset of disease stirs in a sick man" (Tr. Kaster).

2 "We'll succeed in avoiding anger if we promptly lay out before us all of anger's vices and form a 
As a sort of paroxistic complement to the repertoire of monstrous characters that $D e$ ira displays in its attempt to "lay out before us all of anger's vices", the main goal of Medea becomes the vivid and tragic incarnation of the theoretical description of anger laid out throughout the first two books of De ira; it becomes, to borrow from Chaumartin, "a didactic account of a thesis"3, the main aim of which is to put across certain specific doctrines that a merely theoretical approach cannot accomplish.

Although the pedagogic function of Medea (along with the rest of the exempla qua vites (De ira 3.22.1) that are represented by most of the main characters of Seneca's tragedies) has been heatedly discussed throughout the last six decades, and although a strictly programmatic interpretation of Seneca's tragedies like the one proposed by Berthe Marti long $\mathrm{ago}^{4}$ is currently out of favor among interpreters, the elements we find in Medea that clearly derive from De ira are too numerous and too central to be ignored. A basic list of those elements could be summed up in the following ideas concerning the nature and features of anger: i) that, unlike other passions, anger expresses itself in a multiplicity of externally perceptible manifestations ${ }^{5}$; ii) that anger seeks any object to attack when it has become deprived of its original target; iii) that, in a stark contrast to the Stoic sage, the actions and thoughts of a person who is possessed by anger are marked by fluctuations and inconstantia ${ }^{6}$; iv) that the angry person may even be willing to sacrifice his own life or well-being if that is what it takes for the injustice to be avenged ${ }^{7}$; v) that the angry person's criterion of what constitutes a fair reparation of the original injustice that triggered his anger tends to be completely irrational and disproportionate ${ }^{8}$; finally, vi) that the passion of anger, once it has been unleashed, cannot be restrained or brought under control (i.e., that the angry person is not responsive to reasons ${ }^{9}$ ), and vii) that it can only be controlled or checked by another

sound estimation of it. It must be arraigned before us and condemned; its evils must be searched out and made plain; it must be set side by side with the worst vices, so the sort of thing it is becomes clear" (Tr. Kaster). Cf. also De ira 2.36.2-3; 3.3.6.

${ }^{3}$ Cf. Chaumartin 2014, 660.

${ }^{4}$ Cf. Marti 1945.

${ }^{5}$ Cf. De ira 1.1.4-7; 2.35.3-6; 3.4.1-3; Med. 382-91; 850-65.

${ }^{6}$ Cf. De ira 1.17.4; 1.17.7; Med. 123-4; 382-95; 895-900; 916-53; 988-92.

${ }^{7}$ Cf. De ira 1.1.1; Med. 427-9; 591-594.

${ }^{8}$ Cf. De ira 3.31.3; 3.40.2-3.

${ }^{9}$ Cf. De ira 1.1.2; 1.18.2; 1.7-8; 2.3.4; 2.4.1-2; Med. 155; 203-4. Cf. also (in parallel to Med. 155) Ep. 85.8. 
passion (in the case of Medea, by maternal love), but not by reason ${ }^{10}$.

In the following pages, I want to defend the idea that the previous list is missing two central elements which are closely linked and which, as far as I am aware, have not been sufficiently noticed by interpreters. The first idea is that, alongside the elements listed above, Seneca's Medea serves an additional pedagogic function, which comes to light when we ask ourselves not what Medea actually does throughout the play, but rather what she is unable to $d o$, from a psychological perspective: what Medea is incapable of doing is of forgiving or, at the very least, of remaining indifferent to the injustices that (she thinks) are being committed against her. One of the main contributions of the play becomes thus to show in precise detail the consequences (not only to Medea but also to those who surround her) of not being able to let go, of judging that injuries must be avenged. The second point is that not only does Medea have a great deal to say on the question of whether the angry person is responsive to reasons, but also that it can therefore throw considerable light on a recent debate concerning the specific psychology of action that belies the description of anger presented in De ira. I will address these two elements in the reverse order.

\section{Revenge and justice}

The idea that, once the passion of anger has been unleashed, the angry person is blind to reasons, i.e., that he will not change his mind concerning his perceived necessity for revenge, has been usually considered a central feature of the passion of anger, and the reasons for this can be found scattered throughout De ira ${ }^{11}$. Can we find equivalent statements in Medea? Not as clear or explicit as we might want. However, two famous descriptions of Medea's state of mind (one from the Nurse and the other from the Chorus ${ }^{12}$ ) might be taken to imply a similar idea:

\{NVTRIX\} Alumna, celerem quo rapis tectis pedem? resiste et iras comprime ac retine impetum.

Incerta qualis entheos gressus tulit cum iam recepto maenas insanit deo

${ }^{10}$ Cf. De ira $1.8 .7 ; 1.10 .1 ; 1.17 .4 ; 2.14 .1 ; 3.13 .7 ; 3.40 .2$.

${ }^{11}$ Cf. De ira $1.1 .2 ; 1.18 .2 ; 1.7-8 ; 2.3 .4 ; 2.4 .1-2$.

${ }^{12} \mathrm{As}$ I will point out later, the fact that these descriptions come from the Nurse and the Chorus is of considerable significance. 
Pindi niualis uertice aut Nysae ingis, talis recursat huc et huc motu effero, furoris ore signa lymphati gerens. flammata facies, spiritum ex alto citat, proclamat, oculos uberi fletu rigat, renidet: omnis specimen affectus capit. haeret: minatur aestuat queritur gemit. quo pondus animi uerget? ubi ponet minas? ubi se iste fluctus franget? exundat furor. non facile secum uersat aut medium scelus; se uincet: irae nouimus ueteris notas.

magnum aliquid instat, efferum immane impium:

uultum Furoris cerno. di fallant metum! (Med. 380-97) ${ }^{13}$

\section{\{CHORVS $\}$ Quonam cruenta maenas}

praeceps amore saeuo

rapitur? quod impotenti

facinus parat furore?

uultus citatus ira

riget et caput feroci

quatiens superba motu

regi minatur ultro.

quis credat exulem?

Flagrant genae rubentes, pallor fugat ruborem. nullum uagante forma seruat diu colorem. huc fert pedes et illuc, ut tigris orba natis cursu furente lustrat Gangeticum nemus. Frenare nescit iras Medea, non amores; nunc ira amorque causam iunxere: quid sequetur? (Med. 849-69) ${ }^{14}$

13 "Mistress, why are you rushing away from the house? / Stop, suppress your anger, control yourself. / As a Maenad staggers on uncertain feet, / mad with the inspiration of the god, / on the peak of snowy Pindus or Mount Nysa, / so she runs to and fro, her movements wild, / her face displays her crazy passion's marks. / Her cheeks are flaming and she draws deep breaths, / she shouts, her eyes are wet with tears, she smiles; / she shows the signs of every kind of passion. / Hesitant, aggressive, raging, bitter, full of grief. / Where will the weight of her angry heart tip down? / Where will this wave break? Her madness froths over. / The crime she contemplates is complex and extreme: / she will outdo herself; I recognize this passion. / She intends some terrible deed, wild and unnatural. / I see the face of Passion. Gods, prove my fear false!" (Tr. Wilson)

14 "Where is this blood-stained Maenad rushing, / headlong, seized by barbarian lust? / What crime does she plot / in her violent fury? / Her face roused up in anger / is glazed, she shakes her head / proudly, wildly; / she sets out to threaten the king. / Who would believe her an exile? / Her cheeks flame red, / her pallor puts her blush to flight. / She keeps no colour long, / her shape is ever-changing. / Here and there she moves her feet / as a tigress, her cubs lost, / scans the groves of the Ganges / on thunderous paws. / Medea cannot understand restraint / for anger, or for love. / Now anger and love 
But is Medea's furor a state of mind which is actually blind to reasons? Are her actions completely devoid of interaction with and hermetic towards any new reason that could be produced in order to persuade her to divert from her initial path - i.e. vengeance? The fact that, in a clear departure from Euripides' version, the nurse and Jason barely attempt to persuade her to put down her arms, can be taken to imply that that is exactly the idea that Seneca is trying to convey, i.e., that she is completely impervious to any reasoning or exhortation.

A close reading of Medea's monologues, however, leads us to the opposite conclusion, and makes it absolutely clear that, despite what the Nurse or the Chorus would like us to believe, Medea is not a frenzied Maenad: we may abhor her actions, but, as Berry stresses, "there is method in this madness" (Berry 2001, 11) ${ }^{15}$. Her actions, even the most heinous of them ${ }^{16}$, are merely the expression of arguments which have as two of its premises the ideas that an injury has been committed, and that it must be avenged. To a certain extent (and leaving aside, for practical reasons, the existential and literary aspects of the play), we might say that what structures the play from the first to the last verse is the dynamic between a question and an exhortation: the question is a moral/legal one (not devoid of a cosmic aspect): has Jason's initial crime (his disloyalty) been sufficiently punished yet? Is it enough already? Until the double filicide has been committed, this question is systematically met with a negative answer and an exhortation not to quit, not to feel satisfied, before adequate reparation for the injury has been achieved: after the initial opening lines, where Medea asks the divinities to come in her aid so as to make it possible that Jason's disloyalty does not go unpunished, Medea asks herself (in vv. 19-21) if Jason's death is punishment enough, after which she ends her first monologue with an exhortation to herself to resort to her antiquis vigoris in order to adequately accomplish her vengeance (vv. 40-55). This interplay between the question concerning whether the injury has been repaid, and the exhortation to not quit

have joined / to give her a cause: what will happen?" (Tr. Wilson)

${ }^{15}$ It is apt to quote here Berry's words: "Nowhere is Medea unconscious of the goal or the means of her insane drive. Nowhere and at no time does she appear out-of-control, pulled unwillingly along by the riptide of emotion. [...] Medea is frightfully aware and frightfully in control. The playwright's use of metaphors such as eruptions, wild beasts, flood, and fire, even his insistence elsewhere that love and anger are insanities, does not bear with it the modern belief that a person (or thing) acting outside the guidance of reason is less aware of the consequences of the action." (Berry 2001, 11-2).

${ }^{16}$ It is possible, of course, to read Medea's actions in a more favorable light, as does Schiesaro 1997, $107-9$, but that bears no consequence on my main point on the rationality of her actions. 
ahead of time, repeats itself, more or less explicitly, in, at least, four more occasions: vv. 1249; 397-410; 895-910; 976-85. The opening lines of Medea's central monologue are certainly the most apt example:

\{MEDEA\} Quid, anime, cessas? sequere felicem impetum. pars ultionis ista, qua gaudes, quota est? amas adhuc, furiose, si satis est tibi caelebs Iason. quaere poenarum genus haut usitatum iamque sic temet para: fas omne cedat, abeat expulsus pudor; uindicta leuis est quam ferunt purae manus. incumbe in iras teque languentem excita penitusque ueteres pectore ex imo impetus uiolentus hauri. (Med. 895-904) ${ }^{17}$

Considered from this perspective, Medea becomes a play less about passions than about justice (or, at least, that's what Medea thinks); it is a play about vengeance, due punishment and reparation; it is, in other words, a play about the restitution of an order that has been altered (or so Medea thinks) ${ }^{18}$. As Gianni Guastella has shown ${ }^{19}$, despite their complexity and monstrous consequences, Medea's acts are built upon an extremely precise and mathematically clear legal rhetoric: each and every one of her deliberations and actions (the murders of Creusa, Creon and her own children) represent a necessary step in the logic of reparation and compensation that guides her revenge.

Seneca does not, in this sense, represent the sort of cases depicted in De ira 1.16 and 2.5, which are cases of individuals who -for different reasons- have become cruel and inhuman and whose anger is no longer driven forth by the desire to repair an injustice. Medea does not merely want revenge: she wants her revenge to be proportionate to the injury that has been inflicted on her, and her self-exhortation to not quit before reparation has been accomplished is precisely a desire to correct a balance that has been altered. The whole dynamic of the play is built around the need to calculate with utter precision the punishment

17 "Why hesitate, my soul? Follow your lucky strike. / This is a tiny fraction of your triumph. / You are still in love, mad heart, if this is enough: / to see Jason unmarried. Look for new punishment, / unprecedented, and prepare yourself: / let all morality be gone, and exile shame; / that vengeance is too light which clean hands can perform. / Spur on your anger, rouse your weary self, / from the depths of your heart draw up your former passions / with even greater violence" (Tr. Wilson).

${ }^{18}$ The fact that, in contrast to Euripides' version, Seneca decides to place Medea's call for divine help as the opening of the play only serves to stress this structure.

19 Vid. Guastella 2001. Cf. also Schiesaro's analysis of the logic behind Atreus' actions in Thyestes: Schiesaro 2003, 105-19. 
that Jason's crime deserves, and, as disproportionate and wrong as her calculations may be, she is still convinced that she is merely exacting justice through the killing of Creon, Creusa and her own children ${ }^{20}$. That her criteria of what constitutes due reparation is completely disproportionate is, incidentally, what Seneca intends to stress: angry people are - among other things - terrible judges of the actual relevance and consequences of (what they perceive) as injuries or injustices, and their book-keeping tends to be completely biased in their own favor $^{21}$.

How this bears on the question of whether (or to what extent) the angry person is responsive to reasons is, I believe, evident: Medea is not unresponsive to every reason, she is just unresponsive to right-reason (which, in this case, is embodied by every other character, be it Jason, the Nurse, or Creon). She is not, however, unresponsive to her own reasons. What is more: considered from the perspective of the inner workings of her mind, her plans and deliberations exhibit a clear flexibility and are decidedly permeable to Medea's inner reasoning. It is this fact which accounts for her inconstancy, her fluctuations and her sensitivity to her children's gaze (short-lived as that sensitivity may be) ${ }^{22}$. It is even striking that rather than being systematically stubborn, Medea is excessively flexible in her decisions and deliberations (a clear mark of ignorance, from a Stoic perspective). Medea's actions / deliberations are, in this sense, not the unidirectional result of a decision that has been taken once and for all and which she blindly puts into work: her desire is, we might say, an organism, a living organism that interacts with other impressions (phantasiai) that come to Medea's mind, be it other passions (such as pity) or reasons. It is true that the reasons and arguments that her mind constructs are sick and distorted, but what Seneca intends to stress is that they are, nevertheless, reasons and arguments. Her actions, in other words, can be fully explained by an intellectualist psychology of action like the one defended by orthodox Stoicism.

\footnotetext{
${ }^{20}$ An alternative explanation can be found in Gill 1987, 32-3, where it is suggested that at a certain moment (in the center of her central monologue), Seneca's Medea (as opposed to Euripides') drops her quest for a moral justification of her options and embraces them as desirable because they are evil.

21 "You don't keep true accounts: you put a high value on what you've given, a low value on what you've received" (De ira 3.31.3).

${ }^{22}$ On the issue of inconstantia in Seneca's characters, cf. Tietze 2007, as well as Henry and Walker $1967,175-6$.
} 


\section{Medea and De ira}

Where does this lead us concerning the psychology of action elaborated throughout $D e$ ira? On the basis of what I have stressed so far, Medea certainly confirms that the angry person is "shut off from rational deliberation" (rationi consiliisque praeclusa) and "unable to discern what's fair and true" (ad dispectum aequi verique inhabilis) (De ira 1.1.2). Although Medea can certainly change her mind as the result of the inner motions of her mind, she is clearly unresponsive to right reason or to any external reason, and none of Jason's, Creon's or the Nurses' arguments and exhortations can turn her mind away from the goal of avenging Jason's treason. Her mind is made up from the very beginning concerning the fact that an injustice has been committed and that it must be avenged ${ }^{23}$.

This feature of anger, i.e., its blindness to reasons, has been frequently approached through the lens of a sequence of three stages described in De ira:

Et ut scias quemadmodum incipiant adfectus aut crescant aut efferantur, est primus motus non uoluntarius, quasi praeparatio adfectus et quaedam comminatio; alter cum uoluntate non contumaci, tamquam oporteat me uindicari cum laesus sim, aut oporteat hunc poenas dare cum scelus fecerit; tertius motus est iam inpotens, qui non si oportet ulcisci uult sed utique, qui rationem euicit. Primum illum animi ictum effugere ratione non possumus [...]. Alter ille motus, qui iudicio nascitur, iudicio tollitur. (De ira 2.4.1) $)^{24}$

As David Kaufman has stressed, "the only belief correlated with the emotion itself is the conclusion of the beliefs involved in the second movement, stripped of any reference to one's reasons for holding it" (Kaufman 2014, 122). Although his anger may have arisen from what the agent perceives as an injury that needs to be avenged, once the third stage has been reached, all that remains is the need for revenge, irrespective of what set it in motion ${ }^{25}$.

${ }^{23}$ As I insisted in the previous section, this does not mean that Medea's actions are the mechanical outcome of a rigid plan, since neither the exact measure of her revenge nor the means to achieve it are clear to her from the beginning.

24 "To make plain how passions begin or grow or get carried away: there's the initial involuntary movement - a preparation for the passion, as it were, and a kind of threatening signal; there's a second movement accompanied by an expression of will not stubbornly resolved, to the effect that «I should be avenged, since I've been harmed» or «this man should be punished, since he's committed a crime». The third movement's already out of control, it desires vengeance not if it's appropriate but come what may, having overthrown reason. We cannot avoid that first mental jolt with reason's help [...]. That second movement, which is born from deliberation, is eradicated by deliberation" (Tr. Kaster).

${ }^{25}$ I will not go into the details of the exegetical problems that De ira 2.4.1 presents. Two recent approaches to this specific passage can be found in Kaufman 2014, and Graver 2007, 125-32, both of whom discuss Sorabji's famous and controversial account. 
If we approached Medea exclusively from this perspective, however, we would be failing to perceive one of its most important contributions, since what the play shows us is an aspect of anger that was virtually absent in De ira. What Seneca is able to bring to the stage throughout Medea is the distance that separates what anger actually is and what the angry person actually thinks that it stands for, a distance that, incidentally, accounts for the difference between the perspectives of Medea, on the one hand, and the Chorus, the Nurse and Jason, on the other, when it comes to account for Medea's actions. What is the cause of this difference between both accounts? Are not the Chorus, Jason and the Nurse right in seeing Medea's revenge as a blind frenzy? They are: Medea's deliberations are definitely blind to any reason that is presented to her, and none of those reasons is even pondered by her as an alternative to take into consideration ${ }^{26}$. However, Medea does not see it that way, and that is the whole issue: what she sees (and claims) is that she is merely correcting a wrong that has been made, and not only does she not consider her actions as irrational - she considers them to be the incarnation of morality itself. In other words, the desire for revenge that triggers and sustains anger is indeed a blind desire, but (and this is Medea's first contribution to the Stoic account of anger) the angry person cannot confess that to himself: he needs to convince himself that his actions are fully justifiable on account of being the reparation of an injury that has been committed. He needs to make his anger a matter of justice, and he needs to appear (in his own eyes as well as in the eyes of others) as a judge who is merely correcting a balance that has been altered ${ }^{27}$.

This leads us to the second element that I want to stress, i.e., the perceived need for the injustice to be avenged.

\section{Anger, forgiveness and indifference}

Throughout the whole of De ira (though more prominently in Book 3), Seneca presents a wide range of arguments against anger: 1) The world is full of vice and vicious

\footnotetext{
${ }^{26}$ Does this mean that we can apply the sequence from De ira 2.4.1 to Medea's actions? To a certain extent: yes. To use Sorabji's terms, we might say that Medea has certainly shifted "from 'revenge is appropriate' to 'I must be revenged"' (Sorabji 2000, 62), come what may (utique). But the crucial point is that she never realizes that she has done so.

${ }^{27}$ That Medea firmly believes that the whole issue has to do with justice and with righting a wrong can be seen most clearly from vv. 531-7, where she claims to be willing to let the gods decide whether it is her who is right (in desiring revenge) or whether it is Jason.
} 
people; if we were to get angry at every injury, we would constantly live enraged ${ }^{28}$. 2) We all make mistakes and, through them, offend or injure others (and it is not only we who do that, but also the wisest of human beings); if we were to get angry at others for their mistakes, we would be immediately liable to the same reaction on account of our own mistakes ${ }^{29} .3$ ) We often commit the same faults that trigger our anger when committed by others ${ }^{30}$. 4) The reports that come to us of an offense or injustice are often (deliberately or non-deliberately) false; if so, we should be cautious in our reactions ${ }^{31}$. 5) We are imprecise and extremely biased bookkeepers ${ }^{32}$. 6) Contrary to what Aristotelians believe, anger does not work either effectively or efficiently as a stimulus to action, given that, once it has been unleashed, we cannot regain control and will lead us wherever it wants, and not where we had decided ${ }^{33} .7$ ) Contrary to what Aristotelians believe, everything we do under the spur of anger can be accomplished (and with better results) with the aid of reason; in no situation, therefore, is anger a necessary evil ${ }^{34} .8$ ) Every individual is determined at every moment by the moral and epistemic disposition of his soul, to act as he does; the logical reaction to each and every injury and offense we are faced with is not anger but rather understanding and tolerance ${ }^{35}$.

As is evident, not all of these arguments intend to answer the same questions, and the reasons they provide can be (disproportionately) classified under two main groups: a) anger is not advisable on practical (self-centered) grounds: if we are prone to get angry often, that will have undesirable consequences regarding our personal well-being ${ }^{36}$; b) anger is an unjust and illegitimate reaction to an injury or offense, and it should be, therefore, avoided. This difference should not be seen as a problem in Seneca's approach; it should rather be seen as an expression of the fact that his is a fundamentally realistic, quasi-pragmatic, approach to the problem of human passions like anger. Whether it be, then, for the sake of justice or for

${ }^{28}$ Cf. De ira 2.9.1; 3.25.1-2.

${ }^{29}$ Cf. De ira $2.10 .6 ; 3.25 .1-2 ; 3.26 .4-5$.

${ }^{30}$ Cf. De ira 2.28.1; 3.12.1.

${ }^{31}$ Cf. De ira 2.22.2-4; 2.24.1-2; 2.29.2.

${ }^{32}$ Cf. De ira 3.31.3.

${ }^{33}$ Cf. De ira $1.9-12 ; 1.17 .4 ; 1.17 .7$.

${ }^{34} \mathrm{Cf}$. De ira $1.9-12$.

${ }^{35} \mathrm{Cf}$. De ira 2.10.1-2; 6; 3.12.2-3.

36 "Do you see what a life of turmoil you're sentencing yourself to? What sort of life will the person have who's forever inflamed?" (De ira 3.27.4) 
reasons of personal well-being, we should avoid anger altogether, and replace it with a wholly different range of attitudes, attitudes which include, among others and in order of commitment, mere indifference ${ }^{37}$, forgiveness ${ }^{38}$, and repaying an aggression with friendship ${ }^{39}$. It is precisely this option that Medea fails to perceive ${ }^{40}$, and it is this the second element that I suggested at the beginning that Medea manages to put forward in a way that De ira can't, i.e., the impossibility of letting go of the offense, of letting the injustice go unpunished (by us). Why Medea is not capable of forgiving or letting go of an offense is not the issue: she is just one in the extensive list of characters - usually in a politically empowered position - who cannot conceive of reacting to an injustice by other means than by avenging it. Although he occasionally touches on the subject ${ }^{41}$, what Seneca is trying to bring to our attention is not why we are constituted that way but rather what happens when we are unable to exchange ultio for venia. Considered from the standpoint of the individual, which is the perspective adopted in De ira, the consequence is that we are thus jeopardizing our own well-being:

Huic irasceris, deinde illi; seruis, deinde libertis; parentibus, deinde liberis; notis, deinde ignotis: ubique enim causae supersunt nisi deprecator animus accessit. Hinc te illo furor rapiet, illinc alio, et nouis subinde inritamentis orientibus continuabitur rabies: age, infelix, ecquando amabis? O quam bonum tempus in re mala perdis! (De ira 3.28.1) ${ }^{42}$

Medea, however, can be seen to offer a complementary perspective, for, as is evident, she is not the only one whose well-being is jeopardized. Although his perspective is somewhat different, Jon Berry has hinted at what is at stake in the case of Medea:

It is civilization itself and cohesive humanity that is at risk; for Medea's barbarity, in the end, is the barbarity of the natural will triumphant, unfettered by the civilizing rational mind. Medea's barbarity is

${ }^{37}$ Cf. De ira 3.11; 3.39.1.

${ }^{38} \mathrm{Cf}$. De ira $3.11 ; 3.24$.

${ }^{39}$ Cf. De ira 2.34.4-5; 3.27.1.

${ }^{40}$ This explains, incidentally, why the majority of the passages from De ira that we tend to quote in relation to Medea do not come from Book 3, which is devoted to the problem of the possible cures for anger.

${ }^{41}$ Cf. De ira 2.21 .

42 "You become angry with this person, then with that one; with your slaves, then with your freedmen; with your parents, then with your children; with acquaintances, then with strangers. There are reasons in abundance on every side, unless your mind has interceded to plead for clemency. Rage will seize you on one person's account on this side, on another's on the other, and your frenzy will continue as new sources of irritation continually arise. Come, unhappy man, will you ever feel love? Oh, how you're wasting good time in a bad business!" (Tr. Kaster) 
a power capable of dragging humanity back to its primitive roots or of annihilating it altogether. Although foreign to rational precepts, Medea's barbarity is as common as human anger or unrestrained emotion - windows owned by each of us that look upon the natural soul (Berry 2001, 17).

Taken to its utmost extreme, what Medea faces us with is the fact that it is not just our personal ataraxia and euroia that are at risk because of our impossibility to trade ultio for venia; it is, as Creon rightly feared, the possibility of a social organization built on rational principles. The destruction and bloodshed that anger leaves behind in the final scene are not merely symbolical elements: they are meant to be a (fairly realistic, we might add) prediction of the future of any community that condones anger and the obsessive need for reparation as legitimate ways of dealing with any offense $\mathrm{e}^{43}$.

Whether we take the social/cosmic or the individual approach, what is the upshot of all this? Is Seneca suggesting that we should abandon the perspective of justice altogether? From one perspective, it is true that there are many reasons why a Stoic might not feel too uncomfortable with that conclusion. One of them comes from the fact that we live in the best of all possible worlds and that every event has its place (and function) in a perfect cosmic order $^{44}$. Bearing that in mind, the assumption that our anger is the means through which the order which has been altered by the offense will be restored seems somewhat ludicrous, since it would imply that anger actually represents a cosmic device which is necessary for the cosmic ordered to be maintained. The second reason has to do with the idea that our intervention is not actually necessary for injustices to be punished, given that the actual commitment of the injustice is in itself the worst punishment the offender can receive:

'Quid ergo?' inquis 'inpune illi erit?' Puta uelle te, tamen non erit; maxima est enim factae iniuriae poena fecisse, nec quisquam grauius adficitur quam qui ad supplicium paenitentiae traditur. (De ira 3.26.2) ${ }^{45}$

This need not be the final word, however: consistent with his realistic approach to the

${ }^{43}$ This could be seen to have consequences concerning those interpretations that tend to analyze Seneca's Medea from the perspective of the possible legitimacy of her claim for revenge (either from a historical and political viewpoint or from the perspective of gender), but it need not: what I have focused on in these pages is merely one of the many aspects that are embodied in the play, none of which are meant to be cancelled or displaced.

${ }^{44}$ Cf., inter alia, De providentia $1.3 ; 1.5 ; 3.1$.

45 "You go on: «Well then, is he to get off scot-free?». No, not even if you wanted him to. The greatest punishment for doing wrong is having done it, and no one suffers more grievously than the person sentenced to regret." (Tr. Kaster) Cf. also De ira 2.30.2; 3.5.6. 
extremely complex phenomenon of anger, Seneca makes room for the possibility that we may not be comfortable with letting an injustice go unpunished, and he urges us, if we feel we must avenge the offense, to do it in a rational manner, rather than driven by anger:

'Quid ergo?' inquit 'uir bonus non irascitur, si caedi patrem suum uiderit, si rapi matrem?' Non irascetur, sed uindicabit, sed tuebitur. Quid autem times ne parum magnus illi stimulus etiam sine ira pietas sit? Aut dic eodem modo: 'quid ergo? cum uideat secari patrem suum filiumue, uir bonus non flebit nec linquetur animo?' Quae accidere feminis uidemus, quotiens illas leuis periculi suspicio perculit. Officia sua uir bonus exequetur inconfusus, intrepidus; et sic bono uiro digna faciet ut nihil faciat uiro indignum. (De ira 1.12.1-2)

\author{
Rodrigo Sebastián Braicovich \\ CONICET / Universidad Nacional de Rosario
}

\begin{abstract}
46 "An objection: «Are you telling me that a good man doesn't become angry if he sees his father being murdered, his mother raped?» No, he will not become angry, but he'll be their champion and defender. Why are you afraid that a proper sense of devotion won't goad him sufficiently, even without anger? Or to follow out your same line of reasoning: «Are you telling me that when he sees his father or son being stabbed, a good man will not weep and faint?» - that is, the things we see happen to women whenever the slight hint of danger strikes them. A good man will follow up his obligations undisturbed and undeterred, and in doing the things worthy of a good man he will do nothing unworthy of a man" (Tr. Kaster). Cf. also De ira 3.12.5-6 and 1.19.7-8: "He will always, whenever he imposes punishment, keep this principle in mind: one penalty is inflicted to correct the wicked, another to destroy them. In either case he will keep his eye on the future, not the past (for as Plato says, a sensible man punishes, not because a wrong has been done, but lest one be done; what's done is beyond recall, what's to come can be prevented). Those whom he wants to make examples of stubborn wickedness he will kill for all to see, not only so that they themselves will die but so that by dying they will deter others. You can see how the person who must weigh and judge all these factors should approach the matter at hand - the power of life and death — with the utmost calm and scrupulousness. A sword is not well entrusted to an angry man".
\end{abstract}




\section{References}

Aygon, J.-P. 2000. “Le jeu des passions dans la Médée de Sénèque (v. 893-971).” Vita Latina 160 (1).21-31.

Berry, J. M. 2001. "The Dramatic Incarnation of Will in Seneca's Medea." Journal of Dramatic Theory and Criticism 10 (2).3-18.

Chaumartin, F.-R. 2014. "Philosophical Tragedy?" In Brill's Companion to Seneca. Philosopher and Dramatist, edited by Gregor Damschen and Andreas Hei. Leiden. 653-68.

Gill, C.. 1983. "Did Chrysippus Understand Medea?” Phronesis 28.136-49.

Gill, C. 1987. "Two Monologues of Self-Division: Euripides, Medea 1021-80 and Seneca, Medea 893977." In Homo Viator: Classical Essays for John Bramble, edited by Michael Whitby, Philip R. Hardie, and Mary Whitby. Bristol. 25-37.

Graver, M. 2007. Stoicism and Emotion. Chicago: The University of Chicago Press.

Guastella, G. 2001. "Virgo, Coniunx, Mater: The Wrath of Seneca's Medea." Classical Antiquity 20 (2).197-220.

Henry, D. and Walker, B. 1967. "Loss of Identity: Medea Superest?. A Study of Seneca's Medea." Classical Philology 62 (3).169-81.

Kaufman, D. H. 2014. "Seneca on the Analysis and Therapy of Occurrent Emotions." In Seneca Philosophus, edited by Jula Wildberger and Marcia L. Colish. Berlin. 111-33.

Liebermann, W-L. 2014. “Medea.” In Brill's Companion to Seneca. Philosopher and Dramatist, edited by Gregor Damschen and Andreas Heil. Leiden: Brill. 459-74.

Marti, B. M. 1945. "Seneca's Tragedies. A New Interpretation." Transactions and Proceedings of the American Philological Association 76.216-45.

Monteleone, Maria. 2014. "De Ira." In Brill's Companion to Seneca. Philosopher and Dramatist, edited by Gregor Damschen and Andreas Heil. Leiden. 127-34.

Nussbaum, M. 1996. The Therapy of Desire. Theory and Praxis in Hellenistic Ethics. New Jersey.

Pratt, N. T. 1948. "The Stoic Base of Senecan Drama." Transactions and Proceedings of the American Philological Association 79.1-11.

Schiesaro, A. 1997. "Passion, Reason and Knowledge in Seneca's Tragedies." In The Passions in Roman Thought and Literature, edited by Susanna Morton Braund and Christopher Gill. Cambridge.

Schiesaro, A. 2003. The Passions in Play. Thyestes and the Dynamics of Senecan Drama. Cambridge.

Seneca. 2010a. Tragediae] Six Tragedies. Translated by Emily Wilson. Oxford.

Seneca. 2010b. Anger, Mercy, Revenge. Translated by Robert A. Kaster and Martha Craven Nussbaum. The Complete Works of Lucius Annaeus Seneca. Chicago.

Sorabji, R. 2000. Emotion and Peace Of Mind. From Stoic Agitation to Christian Temptation. The Gifford Lectures. Cambridge.

Staley, G. A. 2010. Seneca and the Idea of Tragedy. Oxford.

Tietze, Victoria. 2007. "The Psychology of Uncertainty in Senecan Tragedy.” Illinois Classical Studies 12 (1).135-41.

Vogt, K. M. 2006. “Anger, Present Injustice and Future Revenge in Seneca's De Ira.” In Seeing Seneca Whole. Perspectives on Philosophy, Poetry and Politics, edited by Katharina Volk and Gareth D. Williams. Leiden. 127-34. 